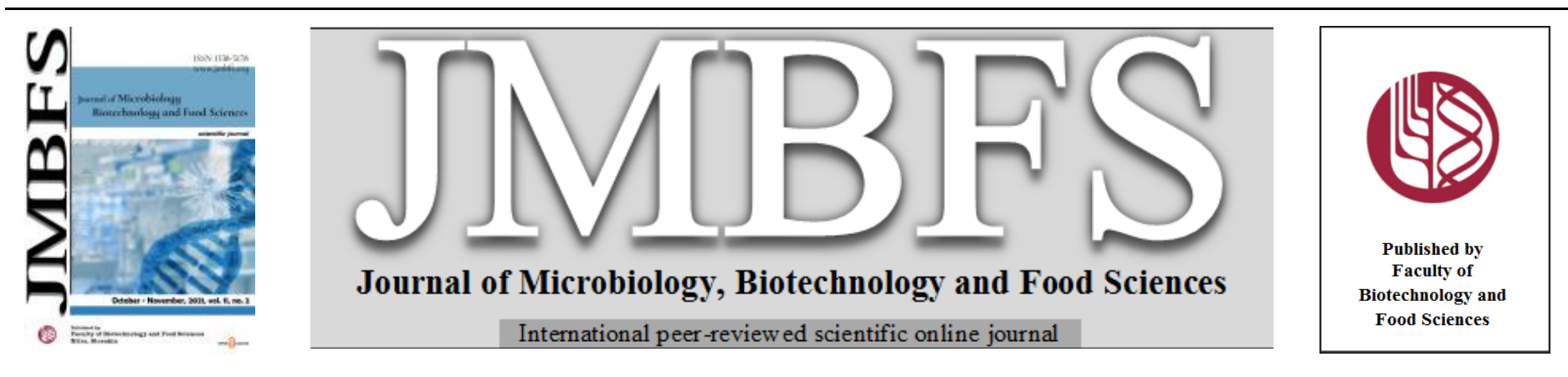

\title{
SEASONAL VARIATIONS OF FATTY ACID COMPOSITION OF COMMON CARP (CYPRINUS CARPIO, L. 1758) FROM AQUACULTURE AND OPEN WATERS IN MACEDONIA
}

\author{
Dijana Blazhekovikj - Dimovska*, Sibel Ahmed ${ }^{2}$ \\ Address(es): Prof. Dijana Blazhekovikj - Dimovska, PhD, \\ ${ }^{1}$ University „St. Kliment Ohridski“, Faculty of Biotechnical Sciences, Department of biotechnology, Partizanska b.b., 7000 Bitola, N. Macedonia, +38978273134. \\ ${ }^{2}$ Food and Veterinary Agency of Republic of N. Macedonia.
}

*Corresponding author: dijanablazekovic@yahoo.com

https://doi.org/10.15414/jmbfs.3213

\section{ARTICLE INFO}

Received 2. 6. 2020

Revised 17. 4. 2021

Accepted 23. 4. 2021

Published 1. 10. 2021

Regular article

OPEN $\partial_{\text {ACCESS }}$

\section{ABSTRACT}

Seasonal variations (spring and autumn) of the fatty acid composition of common carp from aquaculture (cyprinid - warm water fish farm) and open waters (Prespa Lake) from Macedonia were examined. Aquaculture carp contain almost similar saturated fatty acid (SFA) content (25.95\% - spring and 30.77\% - autumn) compared to open water carp (25.84\% - spring and $31.91 \%$ - autumn). Palmitic acid was the major SFA in both aquaculture and open water carp. Regarding monounsaturated fatty acid (MUFA) content, it is significantly higher in both seasons in aquaculture (63.27\% - spring; $59.85 \%$ - autumn) compared to open water carp (48.11\% - spring; $54.12 \%$ - autumn). Oleic acid was identified as the major MUFA. In both seasons, the value of polyunsaturated fatty acid (PUFA) is significantly higher in open water $(26.17 \%$ - spring; $13.97 \%$ - autumn) compared to aquaculture carp (10.90\% - spring; $9.39 \%$ autumn).

The most optimal results in terms of nutritional value of fish meat were found in open water carp, in the spring, due to high PUFA content, especially linoleic (n-6), as well as EPA and DHA (n-3) fatty acids. This is the result of diet, because carp consumes phyto and zooplankton from the lake's benthos, which are especially rich in essential fatty acids.

Keywords: common carp, aquaculture, open waters, fatty acid composition

\section{INTRODUCTION}

In Europe, especially in Central and Eastern Europe, cyprinids are one of the most important fish families, especially in aquaculture production. The Cyprinidae family dominates the world's aquaculture, and common carp (Cyprinus carpio L. 1785) is one of the most consumed fish species belonging to this family (Balon, 2006).

Common carp is one of the most valuable and consumed fish species in Macedonia. It is successfully bred in aquaculture (cyprinid warm water pond and cage farms) in Macedonia, where it covers $60-80 \%$ of the total fish production. Regarding the open waters, common carp is one of the most important components in the overall ichthyomass of Prespa Lake.

According FAO (2006), common carp are omnivorous, with a high tendency towards the consumption of animal food, such as water insects, larvae of insects, worms, mollusks and zooplankton. The carp farming is based on the ability of the species to accept and utilize cereals supplied by the farmers.

Fish is a rich source of omega-3 (n-3) long-chain fatty acids, and the positive effects of these fatty acids on human health have been proven in numerous studies (Von Shacky, 2001; Mozaffarian et al., 2004; Sahena et al., 2009; Barcelo-Coblijn \& Murphy, 2009), which confirms the association of fish consumption with its effect on preventing coronary heart disease, especially myocardial infarction, arteriosclerosis, hypertension and other diseases of the cardiovascular system (Kris-Etherton et al., 2002; Myneris-Perxachs et al. 2010). N-3 long-chain polyunsaturated fatty acids (PUFA) cannot be synthesized in the human body and must therefore be ingested through food (Alasalvar et al., 2002).

Cahu et al. (2004) suggest that freshwater fish may also be a source of n-3 PUFA (EPA and DHA fatty acids), due to the fact that they have a greater ability to dissociate some fatty acids and transform those into PUFA (EPA and DHA) with long chains, unlike marine fish (Lichtenstein et al., 2006).

The aim of this study was to analyze the seasonal variations in the fatty acid composition of common carp meat, which originates from aquaculture (cyprinid warm water fish farm) and open water carp (Lake Prespa), during the spring and autumn

\section{MATERIAL AND METHODS}

In this study, examinations were performed on samples of common carp from two different environments: aquaculture facility (cyprinid fish farm) and open waters (Prespa Lake). Carp samples were taken in the spring and autumn.

The average weight and length of carp samples from aquaculture taken in the spring was $1200 \mathrm{~g}$ and $42 \mathrm{~cm}$, while in the autumn, $1750 \mathrm{~g}$ and $62 \mathrm{~cm}$, respectively.

The average weight and length of carp samples from the lake in the spring was $1450 \mathrm{~g}$ and $70 \mathrm{~cm}$, while in the autumn, $1750 \mathrm{~g}$ and $82 \mathrm{~cm}$, respectively.

The cyprinid fish farm Zhabeni is located in the Bitola region (Macedonia), i.e. the southeastern part of Pelagonia. It was built in $1960 / 61$ by enclosing part of the old riverbed of Crna Reka with two embankments. It covers an area of 170 ha and it is the biggest cyprinid fish farm in Macedonia. The land on the old riverbed of Crna Reka is very fertile, which contributes to the fish farm being very productive, i.e. rich in zoo and phytoplankton. The traditional approach to carp breeding is based on food that is naturally present in the fish farm (zooplankton and benthos, i.e the flora and fauna at the bottom), but the diet is supplemented with unprocessed cereals (wheat, corn, barley).

Prespa Lake is the second largest natural lake in Macedonia. In terms of the composition of the fish settlement, it is typically cyprinid lake. The autochthonous ichthyofauna in Prespa Lake consists of the following fish species: common carp (Cyprinus carpio), Prespa bleak (Alburnus belvica), Prespa spirlin (Alburnoides prespensis), Prespa minnow (Pseudophoxinus prespensis), Prespa spined loach (Cobitis meridionalis) etc.

During examinations, gas chromatography - AOAC method 996.06 for determination of fatty acid composition in fish meat at Veterinary Institute Skopje (Macedonia) was performed.

\section{RESULTS AND DISCUSSION}

The results of the fatty acid composition of the common carp (Cyprinus carpio, L. 1758) from aquaculture and open waters are presented in table 1 and table 2 . 
Table 1 Fatty acid composition (\%) of common carp (Cyprinus carpio, L. 1758) from aquaculture, by seasons

\begin{tabular}{|c|c|c|c|c|}
\hline $\begin{array}{l}\text { Lipid } \\
\text { numbers }\end{array}$ & Name & Type & Spring & Autumn \\
\hline C14:0 & Myristic acid & SFA & 1.39 & 1.31 \\
\hline C15:0 & Pentadecanoic acid & SFA & 0.15 & 0.16 \\
\hline C16:0 & Palmitic acid & SFA & 19.17 & 25.30 \\
\hline $\mathrm{C} 17: 0$ & Heptadecanoic acid & SFA & 0.15 & 0.10 \\
\hline C18:0 & Stearic acid & SFA & 4.99 & 3.80 \\
\hline $\mathrm{C} 24: 0$ & Lignoceric acid & SFA & 0.10 & 0.10 \\
\hline \multicolumn{3}{|c|}{ TOTAL SFA (saturated fatty acid) } & 25.95 & 30.77 \\
\hline C14:1 n-5 & Myristoleic acid & MUFA & 0.10 & 0.17 \\
\hline C15:1 & $\begin{array}{l}\text { Cis-10 - Pentadecanoic } \\
\text { acid } \\
\end{array}$ & MUFA & 0.12 & 0.10 \\
\hline C16:1 n-7 & Palmitoleic acid & MUFA & 13.32 & 13.95 \\
\hline C17:1 & $\begin{array}{l}\text { Cis-10- Heptadecanoic } \\
\text { acid }\end{array}$ & MUFA & 0.55 & 0.31 \\
\hline $\mathrm{C} 18: 1 \mathrm{n}-9 \mathrm{c}$ & Oleic acid & MUFA & 47.83 & 44.00 \\
\hline $\mathrm{C} 20: 1$ & $\begin{array}{l}\text { Cis-11- Eicosenoic } \\
\text { acid }\end{array}$ & MUFA & 1.08 & 1.11 \\
\hline $\mathrm{C} 22: 1 \mathrm{n}-9$ & Erucid acid & MUFA & 0.27 & 0.21 \\
\hline \multicolumn{3}{|c|}{ TOTAL MUFA (monounsaturated fatty acid) } & 63.27 & 59.85 \\
\hline $\mathrm{C} 18: 2 \mathrm{n}-6 \mathrm{c}$ & Linoleic acid & PUFA & 6.88 & 3.54 \\
\hline $\mathrm{C} 18: 3 \mathrm{n}-3$ & $\alpha$ - linolenic acid & PUFA & 1.82 & 2.57 \\
\hline $\mathrm{C} 20: 3 \mathrm{n}-6$ & Eicosatrienoic acid & PUFA & 0.80 & 1.78 \\
\hline $\mathrm{C} 20: 4 \mathrm{n}-6$ & Arachidonic acid & PUFA & 0.56 & 0.33 \\
\hline $\mathrm{C} 20: 5 \mathrm{n}-3$ & Eicosapentaenoic acid & PUFA & 0.27 & 0.45 \\
\hline $\mathrm{C} 22: 6 \mathrm{n}-3$ & Docosahexaenoic acid & PUFA & 0.57 & 0.72 \\
\hline \multicolumn{3}{|c|}{ TOTAL PUFA (polyunsaturated fatty acid) } & 10.90 & 9.39 \\
\hline \multicolumn{3}{|c|}{ Total UFA (unsaturated fatty acid) } & 74.05 & 69.24 \\
\hline \multicolumn{3}{|c|}{ Total PUFA n-6 } & 8.24 & 5.65 \\
\hline \multicolumn{3}{|c|}{ Total PUFA n-3 } & 2.66 & 3.74 \\
\hline \multicolumn{3}{|l|}{$n-6 / n-3$} & 3.09 & 1.51 \\
\hline \multicolumn{3}{|l|}{ n-3/n-6 } & 0.32 & 0.66 \\
\hline \multicolumn{3}{|l|}{ UFA/SFA } & 2.85 & 2.25 \\
\hline \multicolumn{3}{|l|}{ PUFA/SFA } & 0.42 & 0.30 \\
\hline \multicolumn{3}{|c|}{ PUFA/MUFA } & 0.17 & 0.15 \\
\hline
\end{tabular}

Table 2 Fatty acid composition of common carp (Cyprinus carpio, L. 1758) from Prespa Lake, by seasons

\begin{tabular}{|c|c|c|c|c|}
\hline $\begin{array}{l}\text { Lipid } \\
\text { numbers }\end{array}$ & Name & Type & Spring & Autumn \\
\hline C14:0 & Myristic acid & SFA & 2.42 & 3.64 \\
\hline C15:0 & Pentadecanoic acid & SFA & 0.23 & 0.62 \\
\hline C16:0 & Palmitic acid & SFA & 18.97 & 23.72 \\
\hline $\mathrm{C} 17: 0$ & Heptadecanoic acid & SFA & 0.48 & 0.93 \\
\hline C18:0 & Stearic acid & SFA & 3.56 & 2.87 \\
\hline C24:0 & Lignoceric acid & SFA & 0.18 & 0.13 \\
\hline TOTAL SFA & & & 25.84 & 31.91 \\
\hline C14:1 n-5 & Myristoleic acid & MUFA & 0.36 & 0.20 \\
\hline C15:1 & $\begin{array}{c}\text { Cis-10 - Pentadecenoic } \\
\text { acid }\end{array}$ & MUFA & 0.25 & 0.74 \\
\hline C16:1 n-7 & Palmitoleic acid & MUFA & 22.00 & 27.65 \\
\hline C17:1 & $\begin{array}{l}\text { Cis-10- Heptadecanoic } \\
\text { acid }\end{array}$ & MUFA & 1.25 & 1.69 \\
\hline $\mathrm{C} 18: 1 \mathrm{n}-9 \mathrm{c}$ & Oleic acid & MUFA & 22.52 & 21.87 \\
\hline $\mathrm{C} 20: 1$ & $\begin{array}{l}\text { Cis-11- Eicosenoic } \\
\text { acid }\end{array}$ & MUFA & 1.61 & 1.87 \\
\hline C22:1 n-9 & Erucid acid & MUFA & 0.12 & 0.10 \\
\hline TOTAL MUF & & & 48.11 & 54.12 \\
\hline C18:2n-6c & Linoleic acid & PUFA & 9.86 & 1.51 \\
\hline C18:3n-3 & $\alpha$ - linolenic acid & PUFA & 2.20 & 3.02 \\
\hline C20:3n-6 & Eicosatrienoic acid & PUFA & 2.66 & 2.38 \\
\hline C20:4n-6 & Arachidonic acid & PUFA & 0.80 & 1.97 \\
\hline $\mathrm{C} 20: 5 \mathrm{n}-3$ & Eicosapentaenoic acid & PUFA & 5.44 & 2.41 \\
\hline$C 22: 6 n-3$ & Docosahexaenoic acid & PUFA & 5.21 & 2.68 \\
\hline \multicolumn{3}{|l|}{ TOTAL PUFA } & 26.17 & 13.97 \\
\hline \multicolumn{3}{|l|}{ Total UFA } & 74.16 & 68.09 \\
\hline \multicolumn{3}{|c|}{ Total PUFA n-6 } & 13.32 & 5.86 \\
\hline \multicolumn{3}{|c|}{ Total PUFA n-3 } & 12.85 & 8.11 \\
\hline \multicolumn{3}{|l|}{$n-6 / n-3$} & 1.03 & 0.72 \\
\hline \multicolumn{3}{|l|}{$n-3 / n-6$} & 0.96 & 1.38 \\
\hline \multicolumn{3}{|l|}{ UFA/SFA } & 2.86 & 2.13 \\
\hline \multicolumn{3}{|l|}{ PUFA/SFA } & 1.01 & 0.43 \\
\hline \multicolumn{3}{|l|}{ PUFA/MUFA } & 0.54 & 0.25 \\
\hline
\end{tabular}

The results for comparative indicators of fatty acid composition of common carp (Cyprinus carpio, L. 1758) from aquaculture and open waters in spring and autumn are presented in table 3 and table 4 .

Table 3 Comparative indicators of fatty acid composition of common carp (Cyprinus carpio, L. 1758) from aquaculture and open waters, in spring

\begin{tabular}{|c|c|c|c|}
\hline $\begin{array}{l}\text { Lipid } \\
\text { numbers }\end{array}$ & Type & $\begin{array}{l}\text { Fish } \\
\text { farm }\end{array}$ & $\begin{array}{c}\text { Prespa } \\
\text { Lake }\end{array}$ \\
\hline Myristic acid & SFA & 1.39 & 2.42 \\
\hline Pentadecanoic acid & SFA & 0.15 & 0.23 \\
\hline Palmitic acid & SFA & 19.17 & 18.97 \\
\hline Heptadecanoic acid & SFA & 0.15 & 0.48 \\
\hline Stearic acid & SFA & 4.99 & 3.56 \\
\hline Lignoceric acid & SFA & 0.10 & 0.18 \\
\hline TOTAL SFA & & 25.95 & 25.84 \\
\hline Myristoleic acid & MUFA & 0.10 & 0.36 \\
\hline $\begin{array}{c}\text { Cis-10 - Pentadecanoic } \\
\text { acid }\end{array}$ & MUFA & 0.12 & 0.25 \\
\hline Palmitoleic acid & MUFA & 13.32 & 22.00 \\
\hline $\begin{array}{l}\text { Cis-10- Heptadecanoic } \\
\text { acid }\end{array}$ & MUFA & 0.55 & 1.25 \\
\hline $\mathrm{C} 18: 1 \mathrm{n}-9 \mathrm{c}$ & MUFA & 47.83 & 22.52 \\
\hline Cis-11- Eicosenoic acid & MUFA & 1.08 & 1.61 \\
\hline Erucid acid & MUFA & 0.27 & 0.12 \\
\hline TOTAL MUFA & & 63.27 & 48.11 \\
\hline Linoleic acid & PUFA & 6.88 & 9.86 \\
\hline$\alpha$ - linolenic acid & PUFA & 1.82 & 2.20 \\
\hline Eicosatrienoic acid & PUFA & 0.80 & 2.66 \\
\hline Arachidonic acid & PUFA & 0.56 & 0.80 \\
\hline Eicosapentaenoic acid & PUFA & 0.27 & 5.44 \\
\hline Docosahexaenoic acid & PUFA & 0.57 & 5.21 \\
\hline TOTAL PUFA & & 10.90 & 26.17 \\
\hline Total UFA & & 74.05 & 74.16 \\
\hline Total PUFA n-6 & & 8.24 & 13.32 \\
\hline Total PUFA n-3 & & 2.66 & 12.85 \\
\hline$n-6 / n-3$ & & 3.09 & 1.03 \\
\hline$n-3 / n-6$ & & 0.32 & 0.96 \\
\hline UFA/SFA & & 2.85 & 2.86 \\
\hline PUFA/SFA & & 0.42 & 1.01 \\
\hline PUFA/MUFA & & 0.17 & 0.54 \\
\hline
\end{tabular}

Table 4 Comparative indicators of fatty acid composition of common carp (Cyprinus carpio, L. 1758) from aquaculture and open waters, in autumn

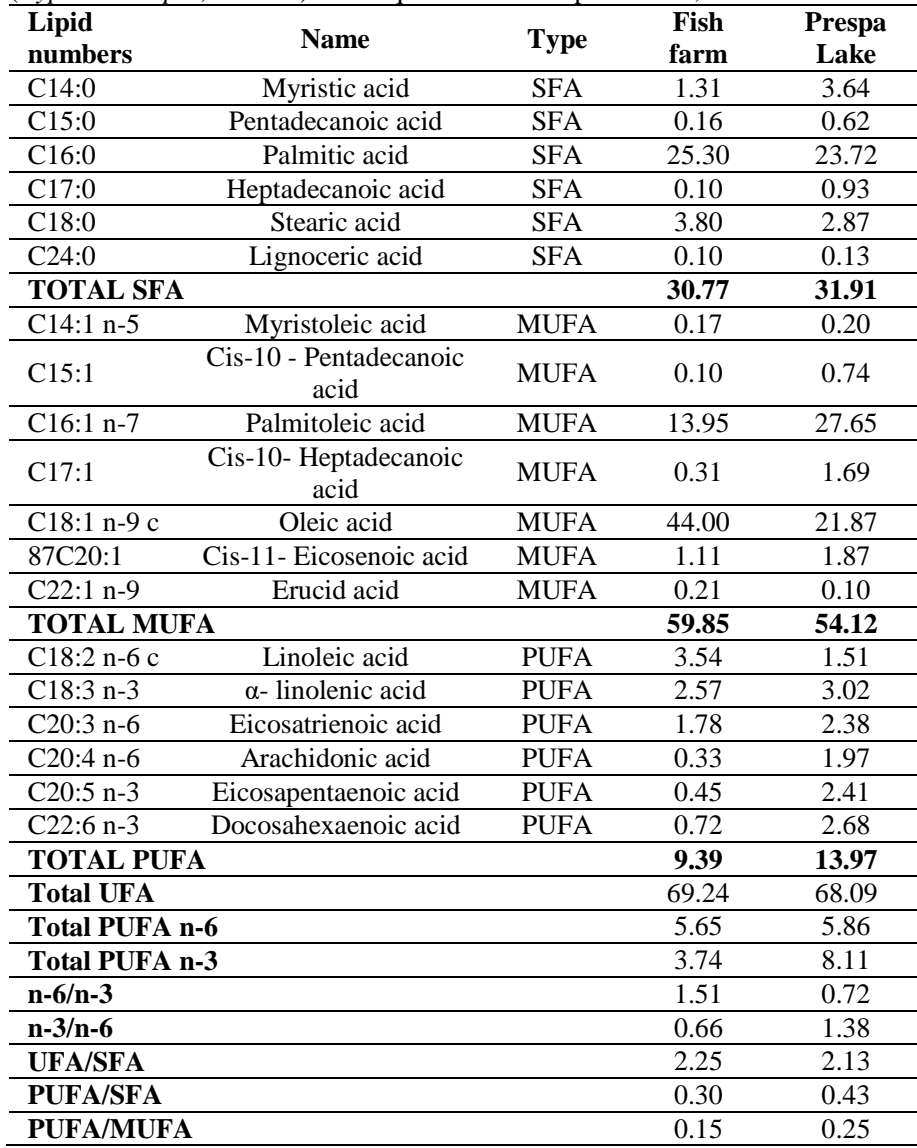


Considering the results of the fatty acid composition of the common carp from aquaculture, in both spring and autumn (Table 1), it can be concluded that in total fatty acid content, SFA participate with $25.95 \%$ (spring) and $30.77 \%$ (autumn) From those, the most dominant are palmitic (19.17\% - spring; $25.30 \%$ - autumn) and stearic (4.99\% - spring; $3.80 \%$ - autumn) fatty acid.

MUFA have the greatest participation in common carp meat, with $63.27 \%$ (spring) and $59.85 \%$ (autumn). From this group, the most dominant is oleic (47.83\% - spring; $44.00 \%$ - autumn), followed by palmitoleic acid $(13.32 \%$ spring; 13.95 - autumn).

PUFA participate with $10.90 \%$ (spring) and $9.39 \%$ (autumn) in total fatty acid content, from which, the most dominant are linoleic $(6.88 \%$ - spring; $3.54 \%$ autumn) and $\alpha$ - linolenic (1.82\% - spring; $2.57 \%$ - autumn), followed by eicosatrienoic $(0.80 \%$ - spring; $1.78 \%$ - autumn), docosahexaenoic DHA $(0.57 \%$ - spring; $0.72 \%$ - autumn), arachidonic (0.56\% - spring; $0.33 \%$ - autumn) and eicosapentaenoic EPA $(0.27 \%$ - spring; $0.45 \%$ - autumn $)$

$\mathrm{N}-6$ (omega 6) fatty acids participate with $8.24 \%$ (spring) and $5.65 \%$ (autumn), while n-3 (omega 3 ) with $2.66 \%$ (spring) and $3.74 \%$ (autumn). The $n-3 / n-6$ ratio is 0.32 (spring) and 0.66 (autumn), while $\mathrm{n}-6 / \mathrm{n}-3$ ratio is 3.09 (spring) and 1.51 (autumn). UFA/SFA ratio is 2.85 (spring) and 2.25 (autumn), PUFA/SFA is 0.42 (spring) and 0.30 (autumn), while PUFA/MUFA is 0.17 (spring) and 0.15 (autumn).

Considering the results of the fatty acid composition of the common carp from open waters (Prespa Lake), in both spring and autumn (Table 2), it can be concluded that in total fatty acid content, SFA participate with $25.84 \%$ (spring) and $31.91 \%$ (autumn). From those, the most dominant are palmitic $(18.97 \%$ spring; $23.72 \%$ - autumn), stearic (3.56\% - spring; $2.87 \%$ - autumn) and myristic (2.42\% - spring; $3.64 \%$ - autumn) fatty acid.

MUFA have the greatest participation in common carp meat, with $48.11 \%$ (spring) and $54.12 \%$ (autumn). From this group, the most dominant is oleic (22.52\% - spring; $21.87 \%$ - autumn) and palmitoleic acid (22.00\% - spring; $27.65 \%$ - autumn)

PUFA participate with $26.17 \%$ (spring) and $13.97 \%$ (autumn) in total fatty acid content, from which, in spring, the most dominant are linoleic (9.86\%), followed by EPA $(5.44 \%)$, DHA $(5.21 \%)$, eicosatrienoic $(2.66 \%), \alpha$ - linolenic $(2.20 \%)$ and arachidonic $(0.80 \%)$ fatty acid. Regarding autumn, $\alpha-$ linolenic $(3.02 \%)$ is represented in the largest percentage, followed by DHA (2.68\%), EPA $(2.41 \%)$, eicosatrienoic (2.38\%), arachidonic (1.97\%) and linoleic (1.51\%) fatty acid.

N-6 (omega 6) fatty acids participate with $13.32 \%$ (spring) and $5.86 \%$ (autumn), while n-3 (omega 3 ) with $12.85 \%$ (spring) and $8.11 \%$ (autumn). The $\mathrm{n}-3 / \mathrm{n}-6$ ratio is 0.96 (spring) and 1.38 (autumn), while $\mathrm{n}-6 / \mathrm{n}-3$ ratio is 1.03 (spring) and 0.72 (autumn). UFA/SFA ratio is 2.86 (spring) and 2.13 (autumn), PUFA/SFA is 1.01 (spring) and 0.43 (autumn), while PUFA/MUFA is 0.54 (spring) and 0.25 (autumn)

With comparison of the results for the fatty acid composition of aquaculture and open water carp (Table 3 and Table 4), it can be concluded that in spring the SFA content is slightly higher in aquaculture carp (25.95\%) compared to open water carp $(25.84 \%)$, while in the autumn the SFA content is slightly higher in open water carp (31.91\%) compared to aquaculture carp (30.77\%).

Regarding MUFA content, it is significantly higher in both seasons in aquaculture carp (63.27\% - spring; 59.85\%- autumn) compared to open water carp ( $48.11 \%$ - spring; $54.12 \%$ - autumn).

In both seasons, the value of PUFA is significantly higher in open water carp (26.17\% - spring; $13.97 \%$ - autumn) compared to that in aquaculture carp (10.90\% - spring; $9.39 \%$ - autumn). Consequently, in the spring, the amount of $\mathrm{n}$ 3 is significantly higher in open water carp (12.85\%) compared to that in aquaculture carp (2.66\%), and the amount of $\mathrm{n}-6$ fatty acids is higher in open water carp (13.32\%) compared to aquaculture carp (8.24\%). In the autumn, the amount of $\mathrm{n}-6$ fatty acids is almost similar in open water carp (5.86\%) compared to aquaculture carp (5.65\%), while the $\mathrm{n}-3$ content is significantly higher in open water carp (8.11\%) compared to aquaculture carp (3.74\%).

In both seasons, the value obtained from the UFA/SFA ratio in aquaculture carp (2.85 - spring; 2.25 - autumn) is almost similar to the value in open water carp (2.86 - spring; 2.13 - autumn), while the PUFA/SFA and PUFA/MUFA ratio are higher in open water carp (1.01 and 0.54 , respectively - spring; 0.43 and 0.25 , respectively - autumn) compared to the values in aquaculture carp ( 0.42 and 0.17 , respectively - spring; 0.30 and 0.15 , respectively - autumn). Also, the value of the $\mathrm{n}-3 / \mathrm{n}-6$ ratio is higher in open water carp (0.96 - spring; 1.38 - autumn) compared to aquaculture carp (0.32 - spring; 0.66 - autumn), while the ratio n-6/n-3 is higher in aquaculture carp (3.09 - spring; 1.51 - autumn) compared to the open water carp (1.03 - spring; 0.72 - autumn).

According to Guler et al. (2008), generally the fish meat has low SFA values $(<30 \%)$, which correlates with our research, where we found SFA content of $25.95 \%$ (spring) $-30.77 \%$ (autumn) in aquaculture carp and $25.84 \%$ (spring) $31.91 \%$ (autumn) in open water carp.

Regarding MUFA, a characteristic feature of freshwater fish is the presence of high levels of oleic and palmitoleic acid (Andrade $\boldsymbol{e t}$ al., 1995), which is correlated with the values obtained in our research, where we found oleic acid content of $47.83 \%$ (spring) - $44.00 \%$ (autumn) in aquaculture carp and $22.52 \%$ (spring) $-21.87 \%$ (autumn) in open water carp, while palmitoleic acid content was $13.32 \%$ (spring) - $13.95 \%$ (autumn) in aquaculture carp and $22.00 \%$ (spring) $-27.65 \%$ (autumn) in open water carp.

Fish that normally consume plankton have high levels of PUFA (Arrayed $\boldsymbol{e t}$ al. 1999). According Steffens \& Wirth (2007), Buchtová et al. (2010), Ćirković $\boldsymbol{e}$ al. (2011), carp grown with natural food from fish farms themselves showed high levels of $n-6$ and n-3 fatty acids. On the other hand carp that was additionally fed with wheat, which is characterized by low content of n-3 fatty acids, results in slightly lower concentrations of these fatty acids and high oleic acid content, which is in correlation with our findings.

Antova et al. (2014) in a study of the fatty acid composition of common carp from cage systems in Bulgaria found that within PUFA, the percentage of $n-6$ fatty acids $(29.80 \%)$ is higher compared to $\mathrm{n}-3$ fatty acids $(5.70 \%)$, which correlates with our findings. The same authors, in a study of the fatty acid composition of carp from fish farms, reservoirs and cage systems in Bulgaria found that the carp from fish farm contains a high percentage of EPA (4.93\%), whose content is 2-12 times higher than the other two researched carp groups. This finding is in correlation with our results, while it is probably due to the good natural nutrient base in the fishpond and the optimal level of zooplankton, which adequately supplement the fish diet based on cereals. This fact proves that growing technology, including the good development of planktonic organisms, is prone to EPA synthesis, which is consistent with our research.

Guler et al. (2008) found that oleic (15.1 - 20.3\%) and palmitoleic (5.1 - 13.2\%) acids are primary and secondary to MUFA in carp in all seasons, which correlates with our findings on the predominance of oleic acid in aquaculture carp $(47.83 \%$ spring and $44.00 \%$ - autumn) and open water carp (22.52\% - spring and $21.87 \%$ autumn), as well as the presence of palmitoleic acid in aquaculture carp (13.32\% - spring and $13.95 \%$ - autumn) and open waters carp (22.00\% - spring and $27.65 \%$ - autumn), where significantly higher values are observed. Kminkova et al. (2001) obtained similar results during the four seasons, i.e. the oleic acid content was significantly higher in aquaculture carp compared to that in open water carp, which is closely correlated with our findings. The data of Yeganeh et al. (2012) show that high levels of oleic acid increase the content of MUFA in all seasons, as the same in our study. The reason for this result is probably due to the nutritional habits of the fish.

According to the results of Kminkova et al. (2001) and Yeganeh et al. (2012) the content of MUFA in carp was higher compared with that of SFA and PUFA in all seasons, while the content of PUFA was lower compared to SFA, which correlates with our findings where we found that the total content of MUFA in carp from aquaculture (63.27\% - spring and 59.85\% - autumn) and open water carp $(48.11 \%$ - spring and $54.12 \%$ - autumn) is significantly higher in both seasons, compared to the contents of SFA and PUFA.

Yeganeh et al. (2012) found that in open water carp, in winter and spring, the PUFA content was higher than in SFA, while in aquaculture carp, PUFA content was highest in all seasons except spring. In open water carp, palmitic, oleic and DHA fatty acids were present in the largest percentage within SFA, MUFA and PUFA, respectively, which is closely correlated with our findings on the predominant participation of these fatty acids in carp from Prespa Lake. In aquaculture carp, the content of SFA and MUFA was similar to that in open water carp, but linolenic acid was present with the highest percentage of PUFA in all seasons. Under SFA, palmitic acid has been primary in carp in all seasons, which correlates with our findings on the predominant presence of this fatty acid in both aquaculture carp (19.17\% - spring and $25.30 \%$ - autumn) and open waters carp (18.97\% - spring and $23.72 \%$ - autumn)

Our results shown significantly higher values of arachidonic AA $(0.80 \%$ - spring and $1.97 \%$ - autumn), EPA (5.44\% - spring and $2.41 \%$ - autumn) and DHA (5.21\% - spring and $2.68 \%$ - autumn) fatty acid in carp samples from open waters compared to those in aquaculture carp. High levels of arachidonic fatty acid have been reported in open water carp by Grigorakis et al. (2002).

Yeganeh et al. (2012) found that open water carp provides consumers with much higher levels of AA, DHA, EPA, n-3, and a more favorable $n-3 / n-6$ ratio, which correlates with our findings. The same authors found that seasonal fluctuations in the fatty acid profile showed that the content of PUFA, n-3 and n- 6 increased during the colder months of the year. These results are attributed to temperature variations, food availability, and reproductive status.

In fish farms, carp use natural and additional food. Vegetable, natural and mineral nutrients and vitamin supplements are used as additional food for the carp offspring. In practice, for rejuvenation and carp fattening, the diet with complete pelleted feed turned out to be satisfactory. The carp is feed additionally only during the summer. The diet of aquaculture carp in this study was based on food that is naturally present in the fish farm (zooplankton and benthos, i.e. the flora and fauna at the bottom), but it was supplemented with unprocessed cereals (wheat, corn, barley).

The benthic zone is essential part of the lake's biotope. Nutrients, organic matter and microorganisms are present here at a much higher density compared to those in fishpond water. The carp covers its food needs from the bottom of the lake, so their characteristics affect the quality of the fish meat, directly through their consumption and indirectly through the water.

Carp specimens that consume natural food from the lake's benthos contain more EPA and DHA, which correlates with our research. The concentration of these fatty acids is high, especially in zooplankton (Steffens et al., 1998). According to 
Guo et al. (2008), the fatty acid composition of plankton varies depending on the seasonal changes. The content of n-3 (especially DHA) is high in cases where cryptophytes and DHA-rich copepods become an important group in the composition of the plankton.

According to Guler et al. (2008), the fatty acid composition of carp muscle tissue may depend on the feeding period and the season. The fatty acid composition, especially the PUFA composition, is essentially controlled by the fatty acid composition of food fats (Bakir et al., 1993).

In the studies of Bauer et al. (2009) the fat content, the fatty acid profile and the total composition of the fish meat were analyzed. These authors concluded that breeding technology has an impact on the fatty acid profile of carp, mainly according to the type of food consumed and the degree of development of the planktonic organisms.

Ćirković et al. (2011) found the possibility to influence the fatty acid composition of fish meat through growing conditions, especially the type of food According to Buchtova et al. (2010) and Ćirković et al. (2012), aquaculture carp grown with natural foods have a high content of both $n-6$ and $n-3$ fatty acids.

According to research of Khorramgah et al. (2007), in aquaculture carp the content of $n-6$ is higher than the content of $n-3$, which is correlated with our research, where in the aquaculture carp the content of n-6 (8.24\% - spring and $5.65 \%$ - autumn) is significantly higher compared to the content of n-3 $(2.66 \%$ spring and $3.74 \%$ - autumn).

The nutritional value of freshwater fish is better compared to marine fish, as the fatty acid composition of freshwater fish is characterized by high proportions of n-6 PUFA, especially linolenic and arachidonic fatty acids. According Malović $\boldsymbol{e}$ al. (2010), the ratio of total $n-3 / n-6$ fatty acids is much lower in freshwater compared to marine fish and ranges from 0.5 - 3 .

The n-3/n-6 ratio is an important indicator of the role of fatty acids in human health, as well as, nutritional value of carp meat (Tokur et al., 2006). According Jabeen (2011), in freshwater fish, the content of $n-6$ is higher compared to the content of n-3. Simopoulos (2002) recommends values from $1.1-1.4$ as an appropriate balance for the n-3/n-6 ratio. According to Steffens et al. (2005), the ratio of $n-3 / n-6$ in the carp varies greatly and ranges from $0.8-2.4$, which is in correlation with our results of $n-3 / n-6$ ratio in open water carp (0.96 - spring; 1.38 - autumn). Other researchers found a lower n-3/n-6 ratio of 0.54 (Cirković et al., 2010), 0.5 (Fajmonova et al., 2003), 0.26 (Trbović et al., 2009) and 0.14 (Ljubojević et al., 2011), which is in correlation with our results of $n-3 / n-6$ ratio in aquaculture carp (0.32 - spring; 0.66 - autumn). Yeganeh et al. (2012) found $\mathrm{n}-3 / \mathrm{n}-6$ ratio higher than 1 in open water carp and lower than 1 in aquaculture carp, so these values are variable during different seasons, which is correlated with the findings obtained from our results.

The n-3/n-6 ratio is generally lower in cultured fish compared to wild fish (Orban et al., 2003), which correlates with the results of our research where it is 0.32 (spring) and 0.66 (autumn) in aquaculture carp and 0.96 (spring) and 1.38 (autumn) in open water carp. The differences in $n-3 / n-6$ ratio can be explained by the wide variability of fat levels in fish muscles, which depends on the species, age, size, reproductive period and the fatty acid composition of food.

In terms of the n-6/n-3 ratio, according to Scollan et al. (2006) the recommended value is less than 4 , which is in correlation with our results, where we obtained 3.09 (spring) and 1.51 (autumn) in aquaculture carp and 1.03 (spring) and 0.72 (autumn) in open water carp.

The UFA/SFA ratio is very important in edible fats. It is believed that the value of this ratio above 0.35 is beneficial to the body. From this point of view, carp fat is good for the human diet. Kminkova et al. (2001) consider a value higher than 0.35 to be sufficient for human health. In our research, this ratio is 2.85 (spring) and 2.25 (autumn) in aquaculture carp and 2.86 (spring) and 2.13 (autumn) in open water carp, which correlated with these recommendations.

The minimum recommended value for the PUFA/SFA ratio is 0.45 (HMSO, 1994) which is closely correlated with our findings of 0.42 (spring) and 0.30 (autumn) ratio in aquaculture carp and 1.01 (spring) and 0.43 (autumn) ratio in open water carp. Ćirković et al. (2011) noted that the PUFA/SFA ratio is most favorable in carp fed with a complete fodder mixture, and less favorable in carp fed in corn and wheat. On the other hand, the PUFA/SFA ratio is recommended to be above 0.4 , so most carp samples in our study have a favorable PUFA/SFA ratio.

\section{CONCLUSION}

Based on the results of our research, it can be concluded that aquaculture carp contain almost similar SFA content $(25.95 \%$ - spring and $30.77 \%$ - autumn) compared to open water carp (25.84\% - spring and $31.91 \%$ - autumn). Palmitic acid was the major SFA in both aquaculture and open water carp. Regarding MUFA content, it is significantly higher in both seasons in aquaculture carp (63.27\% - spring; $59.85 \%$ - autumn) compared to open water carp $(48.11 \%$ spring; $54.12 \%$ - autumn). Oleic acid was identified as the major MUFA in both aquaculture and open water carp. In both seasons, the value of PUFA is significantly higher in open water carp $(26.17 \%$ - spring; $13.97 \%$ - autumn compared to aquaculture carp (10.90\% - spring; $9.39 \%$ - autumn). This difference can be related to the type of diet and the way of growing.
Our research shows that all analyzed carp samples are good source of n- 6 fatty acids (especially linoleic) and n-3 fatty acids (especially $\alpha$-linolenic, EPA and DHA). These results come from the diet of a carp with phytoplankton, which is usually rich in essential fatty acids.

Open water carp contain more n-3 PUFA. However, this amount varies considerably depending on the diet (herbivores, omnivores, carnivores), the fish environment, the fish age, the food origin (natural food or artificial supplements) as its composition (primarily rich in $n-3$ polyunsaturated fatty acids or saccharides).

In industrial production systems, diet is a factor that has the most significant effect on the chemical and fatty acid composition of fish meat, as the composition of the food may partially alter the accumulation of the components that build up the tissue as well as the energy sources. The fat content of meat in fish species that are grown naturally cannot be changed by man and it is influenced by the type and amount of available food. The differences in the fatty acid composition can be influenced by the quality and quantity of the food, especially the availability of phytoplankton.

Generally, the most optimal results in terms of nutritional value of fish meat were found in open water carp, i.e Prespa Lake, in the spring, due to low fat content and high PUFA content, especially linoleic (n-6), as well as EPA and DHA (n-3) fatty acids, which result from the way of feeding, because carp consume natural foods from the lake's benthos itself, i.e phyto and zooplankton, which are especially rich in essential fatty acids.

\section{REFERENCES}

Alasalvar, C., Taylor, K.D.A., Zubcov, E., Shahidi, F. \& Alexis, M. (2002) Differentiation of cultured and wild sea bass (Dicentrarchus labrax): total lipid content, fatty acid and trace mineral composition. Food Chemistry, 79, 145-150. http://dx.doi.org/10.1016/S0308-8146(02)00122-X

Andrade, A. D., Rubira, A. F., Matsushita, M. \& Souza, N. E. (1995). N-3 fatty acids in freshwater fish from South Brazil. Journal American Oil Chemistry 72 (10), 1207-1210. https://doi.org/10.1007/BF02540990

Antova, G.A., Ivanova, A.S., Hadjinikolova, L.D. \& Angelova-Romova, M.J. (2014). Fatty acid composition of lipids in the carp (Cyprinus carpio L.) grown in different production systems. Bulgarian Chemical Communications, 46 (B), 63 67.

Arrayed, F.H., Maskati, H.A. \& Abdullah, F. (1999). N-3 polyunsaturated fatty acid content of some edible fish from Bahrain waters. Estuarine, Coastal and

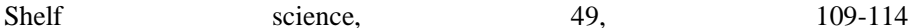
http://bspace.uob.edu.bh/xmlui/handle/123456789/589

Bakir, H.M., Melton, S.L. \& Wilson, J.L. (1993). Fatty acid composition, lipids and sensory characteristics of white grass carp (Ctenopharhyngodon idella) fed different diets. Journal of Food Sciences, 58, 90-95.

Balon, E. K. (2006). The oldest domesticated fishes, and the consequences of an epigenetic dichotomy in fish culture. International Journal of Ichthyology, 11 (2), 47-86.

Barcelo-Coblijn, G. \& Murphy, E. J. (2009). Alpha-linolenic acid and its conversion to longer chain n-3 fatty acids; Benefits for human health and a role in maintaining tissue n-3 fatty acids levels. Progress in Lipid Research, 48, 355-374 https://doi.org/10.1016/j.plipres.2009.07.002

Bauer, C. \& Schlott, G. (2009). Fillet yield and fat content in common carp (Cyprinus carpio) produced in three Austrian carp farms with different culture methodologies. Journal of Applied Ichthyology, 25 (5), 591-594 https://doi.org/10.1111/j.1439-0426.2009.01282.x

Buchtová, H., Svobodová, Z., Kocour, M. \& Velíšek, J. (2010). Chemical Composition of Fillets of Mirror Crossbreds Common Carp (Cyprinus carpio L.) Acta Veterinaria Brno, 79, 551-557. https://doi.org/10.2754/avb201079040551

Cahu, C., Salen, P., \& de Lorgeril, M. (2004). Farmed and wild fish in the prevention of cardiovasular diseases: Assessing possible differences in lipid nutritional values. Nutrition Metabolism and Cardiovascular Diseases, 14, 34-41. https://doi.org/10.1016/s0939-4753(04)80045-0

Čirković, M., Ljubojević, D., Tupan, B., Bogut, I., Đordjević, V., Novakov, N. \& Matekalo - Sverak, V. (2012). Usporedni prikaz kvalitete mesa nekih vrsta riba iz porodice šaranki u Republici Srbiji. Croatian Journal of Fisheries, 70 (1), 79-88. Čirković, M., Trbović, D. \& Ljubojević, D. (2011). Meat quality of fish farmed in polyculture in carp ponds in Republic of Serbia. Meat Technology, 52, 106121. https://www.cabdirect.org/cabdirect/search/?q=sn\%3a\%220494-9846\%22 Čirković, M., Trbović, D., Milošević, N., Đorđević, V., Janković, S. \& Ljubojević D. (2010). Meat quality of two years-old tench and carp grown in extensive conditions. Proccedings of XIV International Symposium Feed Technology (p.p. 286-290). Novi Sad, Serbia, 502 pp.

Fajmonová, E., Zelenka, J., Komprda, T., Kladroba, D. \& Šarmanová, I. (2003): Effect of sex, growth intensity and heat treatment on fatty acid composition of common carp (Cyprinus carpio) fillets. Czech Journal of Animal Science, 48, 8592.

FAO, (2006). Fisheries and Aquaculture Department. Retrieved from http://www.fao.org/fishery/culturedspecies/Cyprinus carpio/en 
Grigorakis, K., Alexis, M.N., Taylor, K.D.A. \& Hole, M. (2002). Comparison of wild and cultured gilthead sea bream (Sparus aurata); composition, appearance and seasonal variations. International Journal of Food Science and Technology, 37, 477-484. https://doi.org/10.1046/j.1365-2621.2002.00604.x

Guler, G.O., Kiztanir, B., Aktumsek, A., Citil, O.B. \& Ozparlak, H. (2008) Determination of the seasonal changes on total fatty acid composition and $\omega 3 / \omega 6$ ratios of carp (Cyprinus carpio L.) muscle lipids in Beysehir Lake. Food Chemistry, 108, 689-694. https://doi.org/10.1016/j.foodchem.2007.10.080

Guo, G.L., Dong, S.L., Zhao, W. \& Chen, W. (2008). Fatty acid composition of plankton and bighead carp (Aristichthys nobilis) in freshwater ponds. Clean, 36, 209-215. https://doi.org/10.1002/clen.200700147

HMSO, UK. (1994). Nutritional aspects of cardiovascular disease (report on health and social subject's No. 46); London: HMSO.

Jabeen, F. \& Abdul, S. C. (2011). Chemical compositions and fatty acid profiles of three freshwater fish species. Food Chemistry, 125, 991-996. https://doi.org/10.1016/j.foodchem.2010.09.103

Khoramgah, M., Rzaei, M., Egagh, S.M. \& Babakhani lashkan, A. (2007) Comparative study of nutritional value and omega - 3 fatty acids in dorsal and ventral mussels of Cyprinus carpio (wild and cultured). Iranian Journal of Science and Marine Technology, 31-37.

Kminkova, M., Winterova, R. \& Kucera, J. (2000). Fatty acids in lipids of carp (Cyprinus carpio) tissues. Czech Journal of Food Sciences, 19 (5), 177-181.

Kris-Ehterton, P. M., Harris, W. S. \& Appel, L. J. (2002). Fish consumption, fish oil, omega-3 fatty acids and cardiovascular disease. Circulation, 106, 2747-2757. https://doi.org/10.1161/01.cir.0000038493.65177.94

Lichtenstein, A. H., Appel, L. J., Brands, M., Carnethon, M., Daniels, S., Franch, H. A., Franklin, B., Kris-Etherton, P., Harris, W. S., Howard, B., Karanja, N., Lefevre, M., Rudel, L., Sacks, F., Van Horn, L., Winston, M. \& Wylie-Rosett, J. (2006). Diet and lifestyle recommendations revision 2006: A scientific statement from the American Heart Association Nutrition Committee, Circulation, 114, 82 96. https://doi.org/10.1161/circulationaha.106.176158

Ljuboević, D., Trbović, D., Lujić, J., Bjelić-Cabrilo, O., Kostić, D., Novakov, N. \& Cirković, M. (2013). Fatty acid composition of fishes from inland waters. Bulgarian Journal of Agricultural Science, 19 (1), 62-71.

Malović, B., Vranić, D., Milošević, N., Matekalo, V., Spirić, A. \& Cirković, M (2010). Sadrzaj nezasićenih masnih kiselina u lipidima mesa slatkovodnih morskih riba, Proccedings of 21. Simpozijum „Stočarstvo, Veterinarska medicina i ekonomika u ruralnom razvoju i proizvodnji zdravstveno bezbedne hrane“"

Mozaffarian, D., Psaty, B. M., Rimm, E. B., Lemaitre, R. N., Burke, G. L., Lyles, M. F., Lefkowitz, D. \& Siscovick, D.S. (2004). Fish intake and risk of incident atrial fibrillation. $\quad$ Circulation, $\quad 110, \quad 368-373$. https://doi.org/10.1161/01.CIR.0000138154.00779.A5

Myneris-Perxachs, J., Bondia-Pons, I., Serra-Majem, L. \& Castellote, A.I (2010). Long-chain n-3 fatty acids and classical cardiovascular disease risk factors among the Catalon population. Food Chemistry, 119, 54-61. https://doi.org/10.1016/j.foodchem.2009.05.073

Orban, E., Nevigato, T., Di Lena, G., Casini, I. \& Marzetti A. (2003). Differentiation in the Lipid Quality of Wild and Farmed Seabass (Dicentrarchus labrax) and Gilthead Sea Bream (Sparus aurata). Journal of Food Science, 68 (1), 128-132. https://doi.org/10.1111/j.1365-2621.2003.tb14127.x

Sahena, F., Zaidul, I. S. M., Jinap, S., Saari, N., Jahurul, H. A., Abbas, K. A. \& Norulaini, N. A, (2009). PUFAs in fish: extraction, fractionation, importance in health. Comprehensive Reviews in food science and food safety, 8, 59-74. https://doi.org/10.1111/j.1541-4337.2009.00069.x

Scollan, N. D., Costa, P., Hallett, K. G., Nute, G. R., Wood, J. D. \& Richardson, R. I. (2006). The fatty acid composition of muscle fat and relationships to meat quality in Charolais steers: influence of level of red clover in the diet. Proceeding of British Society of Animal Sciences (pp. 23), York, UK.

Simopoulos, A. P. (2002). Omega-3 fatty acids in inflammation and autoimmune diseases. Journal of the American College of Nutrition, 21 (6), 495-505. https://doi.org/10.1080/07315724.2002.10719248

Steffens, W. \& Wirth, M. (2007). Influence of nutrition on the lipid quality of pond fish: common carp (Cyprinus carpio) and tench (Tinca tinca). Aquaculture International, 15, 313-319. https://doi.org/10.1007/s10499-007-9088-Z

Steffens, W., Wirth, M. \& Füllner, G. (2005). Freshwater fish-an important source of n-3 polyunsaturated fatty acids: A review. Archives of Polish Fisheries. $13,15-16$.

Steffens, W., Wirth, M. \& Füllner, G. (1998). Fatty acid composition of tench (Tinca tinca L.) under different nutritional conditions. Polish Archives of Hydrobiology, 45, 353-359.

Tokur, B., Çakli, Ş. \& Polat, A. (2006). The quality changes of trout (Oncorhynchus mykiss W., 1792) with a vegetable topping during frozen storage $\left(-18^{\circ} \mathrm{C}\right)$. E.U. Journal of Fisheries and Aquatic Sciences, 23, 345-350.

Trbović, D., Vranić, D., Đinović, J., Borović, B., Spirić, D., Babić, J. \& Spirić, A. (2009). Fatty acid profile and cholesterol content in muscle tissue of one year old common carp (Cyprinus carpio) during growth. Meat technology, 50 (5-6), 276-286.

Von Snacky, C. (2001). Clinical trials, not n-6 to n-3 ratios, will resolve whether fatty acids prevent coronary heart disease. European Journal of Lipid Science and Technology, 103, 423-427.
Yeganeh, S., Bahareh, S., Hedayat, H., Mohammad, R. I. \& Ali, S. (2012). Comparison of Farmed and Wild Common Carp (Cyprinus carpio): Seasonal Variations in Chemical Composition and Fatty Acid Profile. Czech Journal of Food Sciences, 30 (6), 503-511. https://doi.org/10.17221/455\%2F2011-cjfs 